\title{
Development of New Testing Procedures to Measure Propped Fracture Conductivity Considering Water Damage in Clay-Rich Shale Reservoirs: An Example of the Barnett Shale
}

\author{
Junjing Zhang ${ }^{1 *}$, Anton Kamenov ${ }^{2}$, D. Zhu ${ }^{3}$ and A. D. Hill ${ }^{3}$ \\ ${ }^{1}$ Ph.D. candidate at Texas A\&M University. Now with ConocoPhillips Company, Houston, Texas, U.S.A. \\ ${ }^{2}$ M.S. student at Texas A\&M University. Now with Occidental Petroleum, Houston, Texas, U.S.A. \\ ${ }^{3}$ Texas A\&M University, College Station, Texas, U.S.A. \\ * Corresponding author: Junjing Zhang. Tel: +1 832-486-3861. Fax: +1 832-486-2756 \\ Email: junjing.zhang@conocophillips.com
}

\begin{abstract}
Multi-stage hydraulic fracturing is the key to the success of many shale gas and shale oil reservoirs. The main objective of hydraulic fracturing in shale is to create fracture networks with sufficient fracture conductivity. Due to the variation in shale mineralogical and mechanical properties, fracture conductivity damage mechanisms in shale formations are complex. Standard fracture conductivity measurement procedures developed for fractures with high proppant concentration had to be modified to measure the conductivity in fractures with low proppant concentration. Water-based fracturing fluids can interact with the clay minerals in shale and eventually impact shale fracture conductivity. All these challenges require more experimental studies to improve our understanding of realistic fracture conductivity in shale formations.

The aims of this work were to design an experimental framework to measure fracture conductivity created by low concentration proppants and to investigate the mechanisms of conductivity damage by water. We first presented the laboratory procedures and experimental design that can accurately measure fracture conductivity of shale fractures at low concentrations of proppants. Then we measured the undamaged shale fracture conductivity by dry nitrogen. Water with similar flowback water compositions was injected to simulate the damage process followed by secondary gas flow to measure the recovered fracture conductivity after the water damage.

This study shows that the developed laboratory procedures can be utilized to reproducibly measure shale fracture conductivity by both gas and liquid. The conductivity measurement of propped fractures by small size proppants at low concentrations requires strict control on gas flow bypassing the fracture both parallel and perpendicular to the fracture length direction. Shale fracture surface softening is identified as the dominant cause for the significant conductivity reduction after water flow.
\end{abstract}

\section{Introduction}

Laboratory measurement is a direct, controllable, and repeatable approach to study fracture conductivity. Generally, there are two types of laboratory procedures for the measurement, namely, the standard ISO conductivity test and the modified ISO conductivity test. The ISO 13503-5:2006(E) was developed to establish standard procedures and experimental conditions to evaluate conductivity of proppants under laboratory conditions. All test apparatus and conditions under ISO 13503-5:2006(E) are specified to guarantee the proppant evaluation results are comparable. In a word, the standard ISO procedures and apparatus are designed for the purpose of proppant material studies and the measured conductivity is the baseline value without considering more realistic conditions.

The modified ISO test, or non-ISO standard test, on the other hand, has been made by various research parties for different applications. The commonest application is to use a modified API conductivity cell to accommodate 3 times thicker samples to account for fluid leakoff through the sample during the 
experiment. Instead of flowing $2 \% \mathrm{KCl}$ through the fracture as specified by ISO standards, the modified tests can flow dry gas, wet gas, fresh water, brine of various concentrations and multi-phase flow for different reasons, such as protecting the shale sample by flowing dry nitrogen (Zhang et al. 2013; Zhang et al. 2015), keeping the gel hydrated by wet gas (Awoleke et al. 2012), studying the water sensitivity (Conway et al. 2011), and investigating the effect of multiphase flow and non-Darcy flow (Barree et al. 2009). Both cylindrical core plugs and samples of API dimensions ( 7 inch long, 1.5 inch wide with curved ends) are used in the non-ISO tests (Ramurthy et al. 2011). Moreover, proppants are placed on smooth saw-cut Berea sandstone samples in ISO tests while any type of rock with either saw-cut smooth faces or rough faces can be used in the non-ISO tests.

The sensitivity of shale to water has been studied in the areas of drilling engineering and formation damage. Common authigenic clay minerals present in petroleum reservoirs are kaolinite, chlorite, illite, smectite and mixed-layer clays (Civan 2007). Clay particles are very small. The maximum dimension of a typical clay particle is less than 5 micron (Hughes 1951). Formation damage caused by clay swelling, dispersion and migration in sandstone reservoirs were identified during water flooding early in the 1960s (Jones 1964). Clay related porosity and permeability impairment usually happens in two ways: clay swelling and fines migration. Smectite is the most swellable clay mineral. According to Ezzat (1990), smectite is $100 \%$ expandable and it causes tremendous loss of micro-porosity and permeability. However, smectite is not as common as the other clay minerals in most of the reservoirs currently being developed (Conway et al. 2011). Mixed layer clay minerals are also believed to have some swelling ability due to the illite-smectite and chlorite-smectite layers. Clay swelling mechanisms, modeling, porosity and permeability reduction were reviewed by Civan (2007).

The other mechanism of formation damage due to water-clay interaction is fines migration. In sandstone, when the fluid velocity exceeds a critical value, fines would be released from the pores (Gruesbeck et al. 1982). Sharma et al. (1985) derived a model to estimate the rates of fine release and deposition in a single pore. Reservoir permeability is severely impaired due to the release, migration and entrapment of fines at the pore throats. Sharma et al. (1986) also investigated fines entrapment using a statistical approach and general population balance equations. Experimentally, fines migration is observed by a standard water shock experiment where the flow through a sandstone core is suddenly switched from brine to fresh water. It was reported that in the water shock experiment, permeability can be reduced by two orders of magnitude (Khilar and Fogler 1983).

Conductivity damage due to clay-water interaction has been studied during pre-fracturing formation evaluation in shale. The test is called unpropped fracture conductivity test (UFCT). It is done to determine fluid sensitivity to shale rocks and the residual fracture conductivity after different fluid damages. It was reported that the clay-water interaction can reduce shale rock strength, and the variation of shale rock mechanical properties depends on rock mineralogy, fluid compositions and test conditions (Akrad et al. 2011; LaFollette and Carman 2013; Lin and Lai 2013).

There is a need to develop a laboratory framework to accurately measure shale fracture conductivities at low proppant concentration. Shale fracture conductivity damage by water needs to be proved with sound laboratory evidence. Therefore, this work aims at developing new laboratory procedures for shale fracture conductivity measurement and examining the conductivity damage mechanism.

\section{Development of Laboratory Setup and Procedures}

Laboratory setup. The setup was developed for conductivity measurement by both gas and water. The entire apparatus consists of five separate units: (1) gas injection unit; (2) liquid injection unit; (3) conductivity cell assembly; (4) closure stress application unit; and (5) pressure/rate data acquisition unit. Fig. 1 shows the schematic of the apparatus. The photograph of the setup is shown in Fig. 2. 
The gas injection unit consists of a nitrogen tank containing industrial grade dry nitrogen. The nitrogen tank is pressurized up to $2,000 \mathrm{psi}$ and is controlled by a very sensitive spring valve. A digital gas flow controller is connected to the nitrogen tank to measure the gas flow rate. The liquid injection unit includes a 1000D Teledyne ISCO Syringe pump, a PVC refilling accumulator, two stainless steel displacement accumulators, an AW-32 hydraulic oil reservoir and the flow line manifolds. The load frame is capable of applying up to $870 \mathrm{kN}$ force or around $16,000 \mathrm{psi}$ of closure stress on a piston with surface area of $12 \mathrm{in}^{2}$. It can apply closure stress at a rate of 100 psi per minute. The piston's axial displacement is recorded with an accuracy of 0.01 millimeters. The modified API conductivity cell is made of stainless steel and consists of a cell body, two side pistons and two flow inserts (Fig. 3). The cell body is $10 \mathrm{in.} \mathrm{long,} \mathrm{3-1/4} \mathrm{in.} \mathrm{wide,}$ and $8 \mathrm{in}$. in height. The hollow section of the cell is designed to accommodate a pair of core samples that are 7 in. long, 1.65 in. wide, and 3 in. in height (Fig. 4). The top and bottom pistons keep the cores in place and have Viton polypack seal to prevent any fluid leakage. Each piston is 7 in long, 1.65 in. wide, and 3 in. tall and has a hole drilled into its center that is connected to leak-off lines and serves as a conduit of fluids out of the cell during an experiment. The two flow inserts with Viton o-rings connect to flow lines on the upstream and downstream side of the cell. There are three pressure measuring ports drilled through the middle of one side of the cell body. Two of the transducers are used to measure the differential pressure across the length of the fracture while the third one in the middle of the cell is measuring the absolute cell pressure. The transducers can measure the pressure with an accuracy of 0.01 psi. The needle valve connected on the downstream side of the system serves as a back pressure regulator which is used to control the flow rate during the conductivity measurements. More specifications on the setup can also be found in Zhang et al. (2013).

Water Injection Rate. Various authors have emphasized the importance of stabilized flow in conductivity measurement (Barree and Conway 2009; Conway et al. 2011). We controlled the rate to be in the laminar flow regime. The Reynolds number in the porous media is given by,

$$
R_{e}=\frac{\rho v D_{H}}{\mu(1-\phi)}
$$

Where the hydraulic diameter $D_{H}$ for a slot is defined as,

$$
D_{H}=\frac{2 h_{f} w_{f}}{\left(h_{f}+w_{f}\right)}
$$

The Reynolds number for the liquid flow in the experiments are calculated and reported in Fig. 5. In the water experiments, the maximum flow rate is $5 \mathrm{~mL} / \mathrm{min}$ in propped fracture. Obviously, the laminar flow assumption is valid in this study. Fracture conductivity was calculated using Darcy's Law for water and gas. More details about derivation of the calculation formula can be found in the reference (Zhang 2014).

Experimental Procedures. Experiments were run to measure the undamaged shale fracture conductivity and to study the shale fracture conductivity damage by water. Procedures for the experimental approach are shown below:

(1) Screen fracturing design variables to be studied, and examine the factors that impact fracture conductivity in shale; review current industry practices to determine reasonable ranges for the parameters; scale these parameters down to laboratory conditions.

(2) Collect representative shale rock samples and characterize the rocks.

(3) Design laboratory procedures to induce fractures and prepare the samples to fit into the conductivity cell; acquire experimental materials and consumables. 
(4) Perform preliminary tests on the first batch of rock samples to examine the integrity of the apparatus and the modified procedures; review the findings with the advisory committee.

(5) Run experiments extensively to study each of the proposed variables.

(6) Collect evidence that support the findings using microscopic imaging techniques.

Key Design Considerations. In this study, we induced fractures along the laminations of shale samples. Bedding planes in shale are the surfaces that are perpendicular to the direction of sediment settling. So, bedding planes are horizontal during deposition. We recognize that unless the shale bedding layers thrust up to a high dip angle, the bedding planes are not usually the fracture faces as in the horizontal fractures. However, in the outcrop and roadcuts where the samples were collected, we observed the pre-existing fractures can be vertical, horizontal or slanted in certain degrees. This means the weak planes can be of any angle. Properties that dominate fracture conductivity in shale such as rock mineralogy, fracture surface strength to resist embedment and proppant properties are not directional. Therefore, results generated on fracture faces by opening the laminations are representative.

Another consideration of opening weak bedding planes is to have better experiment reproducibility. The modified API conductivity cell requires good fracture alignment to expose the fracture to the pressure sensor ports. Otherwise, differential pressure measurements could be erroneous. This is illustrated in Fig. 6. We attempted to induce fracture perpendicular to the bedding planes. But the fracture deviates towards the horizontal direction along the bedding planes after growing for less than 1 inch. To ensure the measurements are repeatable, we have been using the bedding planes as our fracture faces.

A mold was built to coat the shale sample with silicone rubber compound. The mold has similar dimensions as the conductivity cell except that the slot width is 0.003 inch larger than width of conductivity cell slot width (Fig. 7). The extra 0.003 inch silicone rubber is squeezed into the conductivity cell and can provide good seal between the rock and the cell walls. The mold is wire-cut to ensure a high degree of smoothness on the inside. The height of the mold is $3.5 \mathrm{inch}$.

Procedures were developed to seamlessly coat the fracture with silicone rubber. This method is illustrated by Fig. 8 and the stesps are below:

Step 1: Align the samples and label both sides.

Step 2: Cover the fracture with paint tape before pouring the liquid silicone compound into the mold to keep the liquid epoxy from entering the fracture. Coat the bottom 1.5 inch of the sandstone sample. Wait until the bottom 1.5 inch section is cured and continue coating the middle 3 inch section.

Step 3: Coat the top 1.5 inch sandstone section. Take the sample out from the mold. This is called a blank sample because the rock sample is completely covered by the silicone rubber. Cut windows to expose the fracture to the conductivity cell inlet, outlet, and the three ports for the pressure transducers.

Pressure Test the Modified API Conductivity Cell. Cell assembly integrity is tested to detect gas leakage both parallel and perpendicular to the flow direction. System integrity test procedures and pressure/rate response are discussed below.

As shown in Fig. 9, to detect the vertical flow leakage, close plug valve 2 and 3 and open valve 1. Give a flow impulse to the cell assembly and record the response of differential pressure sensor and cell pressure sensor. Gas rate, cell pressure and differential pressure responses are plotted in Fig. 10.

The rate impulse is represented by the blue line; pressure responses should be observed instantaneously by the differential pressure (pink dashed line) and cell pressure (red solid line) sensors. The cell pressure sensor is attached to the middle measurement port. The differential pressure should drop back to zero because there is no flow rate, while the cell pressure stays at a certain level. Repeating the rate impulse, similar pressure/rate signatures should be observed but the cell pressure now is higher than the previous impulse. Repeat this for a third rate impulse and stop. If the differential pressure line doesn't drop back to zero; instead, it stays at a certain value, then a vertical leakage occurs in the cell assembly. 
To detect the horizontal flow leakage, close plug valve 3, open valve 1 and 2, then put a blank sample into the conductivity cell, as shown in Fig. 11. A blank sample is fully covered by the silicone rubber without cutting the measurement ports or inlet/outlet ports. Gas rate, cell pressure and differential pressure responses are plotted in Fig. 12.

After the first flow impulse, immediate rate and differential pressure responses should be seen as represented by the solid blue line and the dashed pink line. However, the cell pressure sensor should not sense any pressure response if there is no horizontal leakage flow bypassing the sample. Repeat the same rate impulse following the same procedure. If the cell pressure does not keep zero at any of the flow impulses, there is horizontal flow leakage between the blank sample and cell walls. The measured conductivity would be higher than its real value.

\section{Experiment Preparations}

Shale Sample. The outcrop Barnett Shale samples were used in this study. According to Papazis (2005), shale samples collected for this research fall into the category of black to greyish black shale. In this type of shale, natural fractures are usually filled with calcite and can remain open as per the characterization on cores sampled from the subsurface. X-ray Diffraction tests show that the outcrop samples in this study contain 31\% quartz, 32\% illite, 9\% mixed layered illite-smectite and 5\% kaolinite. Another mineral in the Barnett shale outcrop is anhydrite, which is the main natural fracture infill material (Zhang et al. 2013).

Fluids and Proppants. Industrial grade dry nitrogen was used to measure the undamaged fracture conductivity and the recovered fracture conductivity after water damage. PVT properties of nitrogen were calculated using The Engineering Toolbox (2014). Brine with a similar chemical composition to typical flowback water was injected into the fracture after nitrogen to simulate the damage process (Table 1). 30/50 mesh Badger sand collected from an operator's fracturing site was used in this study.

\section{Results and Discussions}

Fracture Conductivities in Barnett shale. Fracture Conductivities were first measured by nitrogen for undamaged fracture conductivity; then water was injected until a steady state flow was reached to damage the fracture; finally nitrogen was flowed again to remove water and the recovered fracture conductivity was measured. The two nitrogen-measured fracture conductivities were compared to evaluate the damage. The fracture was propped by 30/50 mesh sand and the proppant concentration is $0.20 \mathrm{lb} / \mathrm{ft}^{2}$. Consider the typical Barnett Shale reservoir depth and the minimum horizontal stress, the effective closure stress was set at 4,000 psi during the experiment.

Fig. 13 shows the results of one experiment. The undamaged conductivity is $110 \mathrm{md}-\mathrm{ft}$, which is significantly reduced to $2.98 \mathrm{md}$-ft after the water flow. Gas flow recovers the fracture conductivity to 3.19 md-ft. For this particular experiment, $97 \%$ of the initial fracture conductivity is lost due to water flow. According to Zhang et al. (2013), rock creep in the long term conductivity measurement accounts for about $20 \%$ conductivity reduction in the first 20 hours. Therefore, the permanent conductivity reduction by shale-water interaction is about 77\%. Experiments were repeated and similar results were found (Fig. 14).

Post Experimental Analysis. Microscopic images of proppant embedment were taken for experiments either with or without water flow. Fig. 15(a) shows the fracture surface after the conductivity measurement by water. It can be seen that over half of the proppant diameter is buried into the fracture face. Fig. 15(b) shows the Barnett shale fracture that was only exposed to gas. Proppants dropped off from the fracture face because the embedment was shallow, while the embedment was so deep for the fracture which was exposed to water that proppants stayed on the fracture surface after experiments. Clearly, the fracture surface is softened after being exposed to water. 
Direct measurements of rock mechanical properties proved the shale surface softening as a function of water content (Lin and Lai 2013). It was reported that Young's modulus and uniaxial compressive strength of Barnett Shale are strongly correlated to the sample water saturation (Fig. 16). Compared with the dry shale sample, a sample with 35\% water saturation has a $22 \%$ smaller Young's modulus and a 35\% smaller uniaxial compressive strength (UCS).

\section{Conclusions}

We developed laboratory setup and procedures to measure shale fracture conductivities by gas and water. Post experimental analysis helped understand the interaction between shale and water and its detrimental effect on shale fracture conductivity. Based on the experimental studies, the following conclusions were made:

1. Laboratory procedures developed in this study can be utilized to reproducibly measure shale fracture conductivity by both gas and liquid. The conductivity measurement of propped fractures by small size proppants at low concentrations requires strict control on gas flow bypassing the fracture both parallel and perpendicular to the fracture length direction.

2. Significant fracture conductivity was lost after water flow in the Barnett shale under 4,000 psi closure stress. Consider the role of long term rock creep in fracture conductivity reduction, the conductivity loss caused by shale-water interaction is $70 \%$ $90 \%$.

3. The significant conductivity loss was caused by the shale fracture surface softening after its exposure to water. The fracture surface softening was verified by direct measurement of Young's modulus and uniaxial compressive strength reduction after an increment of water content.

\section{Nomenclature}

$\begin{array}{ll}D_{H} & \text { Hydraulic diameter, } \mathrm{m} \\ h_{f} & \text { Width of the shale sample, } \mathrm{m} \\ R_{e} & \text { Reynolds number, dimensionless } \\ v & \text { Fluid velocity in the fracture, } \mathrm{m} / \mathrm{s} \\ w_{f} & \text { Fracture width, } \mathrm{m} \\ \rho & \text { Fluid density, } \mathrm{kg} / \mathrm{m}^{3} \\ \mu & \text { Fluid viscosity, } \mathrm{Pa} \cdot \mathrm{s} \\ \phi & \text { Porosity, fraction }\end{array}$

\section{Acknowledgement}

The author would like to acknowledge the sponsors of Crisman Institute for Petroleum Research in the Petroleum Engineering Department at Texas A\&M University as well as the Department of Energy, and the Research Partnership to Secure Energy for America (RPSEA) for their support of this work (RPSEA project 11122-07TAMU-Zhu).

\section{References}

1. Akrad, O., Miskimins, J. and Prasad, M. 2011. The Effects of Fracturing Fluids on Shale Rock Mechanical Properties and Proppant Embedment. Paper SPE 146658 presented at the SPE Annual Technical Conference and Exhibition, Denver, Colorado, U.S.A., 30 October-2 November.

2. Awoleke, O., Romero, J., Zhu, D., and Hill, A.D. 2012. Experimental Investigation of Propped Fracture Conductivity in Tight Gas Reservoirs Using Factorial Design. Paper SPE 151963 presented at the SPE Hydraulic Fracturing Technology Conference, the Woodlands, Texas, U.S.A., 6-8 February. 
3. Barree, R.D. and Conway, M.W. 2009. Multiphase Non-Darcy Flow in Proppant Packs. SPE Production \& Operations, 24(2): 257-268.

4. Civan, F. 2007. Reservoir Formation Damage. Houston, Texas: Gulf Publishing Company.

5. Conway M., Venditto J., Reilly P., and Smith K. 2011. An Examination of Clay Stabilization and Flow Stability in Various North American Gas Shales. Paper SPE 147266 presented at the SPE Annual Technical Conference and Exhibition, Denver, Colorado, U.S.A., 30 October-2 November.

6. Ezzat, A.M. 1990. Completion Fluids Design Criteria and Current Technology Weakness. Paper SPE 19434 presented at the SPE Formation Damage Control Symposium, Lafayette, Louisiana, U.S.A., 22-23 February.

7. Gruesbeck, C. and Collins, R.E. 1982. Entrainment and Deposition of Fine Particles in Porous Media. SPE Journal, 22(6): 847-856.

8. Jones Jr., F.O. 1964. Influence of Chemical Composition of Water on Clay Blocking of Permeability. Journal of Petroleum Technology, 16(4): 441-446.

9. Horner, P., Halldorson, B., and Slutz, J.A. 2011. Shale Gas Water Treatment Value Chain-A Review of Technologies, including Case Studies. Paper SPE 147264 presented at the SPE Annual Technical Conference and Exhibition, Denver, Colorada, U.S.A., 30 October-2 November.

10. Hughes, R.V. 1951. The Application of Modern Clay Concepts to Oil Field Development. Drilling and Production Practice, 1950: 151-167.

11. ISO 13503-5. 2006. Petroleum and Natural Gas Industries-Completion Fluids and Materials-Part 5: Procedures for Measuring the Long-Term Conductivity of Proppants. First Edition, 1 July.

12. Khilar, C.K. and Fogler, H.S. 1983. Water Sensitivity of Sandstones. SPE Journal, 23(1): 55-64.

13. LaFollette, R.F. and Carman, P.S. 2013. Comparison of the Impact of Fracturing Fluid Compositional pH on Fracture Wall Properties in Different Shale Formation Samples. Paper SPE 166471 presented at the SPE Annual Technical Conference and Exhibition, New Orleans, Louisiana, U.S.A., 30 September-2 October.

14. Lin, S. and Lai, B. 2013. Experimental Investigation of Water Saturation Effects on Barnett Shale's Geomechanical Behaviors. Paper SPE 166234 presented at the SPE Annual Technical Conference and Exhibition, New Orleans, Louisiana, U.S.A., 30 September-2 October.

15. Ramurthy, M., Barree, R.D., Kundert, D.P., Petre, E., and Mullen, M. 2011. Surface-Area vs ConductivityType Fracture Treatments in Shale Reservoirs. SPE Production and Operations, 26(4): 357-367.

16. Papazis, P.K. 2005. Petrographic Characterization of the Barnett Shale, Fort Worth Basin, Texas. MS Thesis. The University of Texas at Austin, Austin, Texas (August 2005).

17. Sharma, M.M., Yortsos, Y.C., and Handy, L.L. 1985. Release and Deposition of Clays in Sandstones. Paper SPE 13562 presented at the SPE Oilfield and Geothermal Chemistry Symposium, Phoenix, Arizona, U.S.A., 9-11 March.

18. Sharma, M.M. and Yortsos, Y.C. 1986. Permeability Impairment Due to Fines Migration in Sandstones. Paper SPE 14819 presented at the 7th Symposium on Formation Damage Control, Lafayette, Louisiana, U.S.A., 26-27 February.

19. The Engineering Toolbox. 2014. http://www.engineeringtoolbox.com/nitrogen-d_1421.html

20. Zhang, J., Kamenov, A., Zhu, D., and Hill, A.D. 2013. Laboratory Measurement of Hydraulic Fracture Conductivities in the Barnett Shale. SPE Production \& Operations, 29(3): 216-227.

21. Zhang, J. 2014. Creation and Impairment of Hydraulic Fracture Conductivity in Shale Formations. PhD Dissertation, Texas A\&M University, College Station, Texas (August 2014).

22. Zhang, J., Kamenov, A., Zhu, D., and Hill, A.D. 2015. Measurement of Realistic Fracture Conductivity in the Barnett Shale. Journal of Unconventional Oil and Gas Resources, 11(2015): 44-52. 

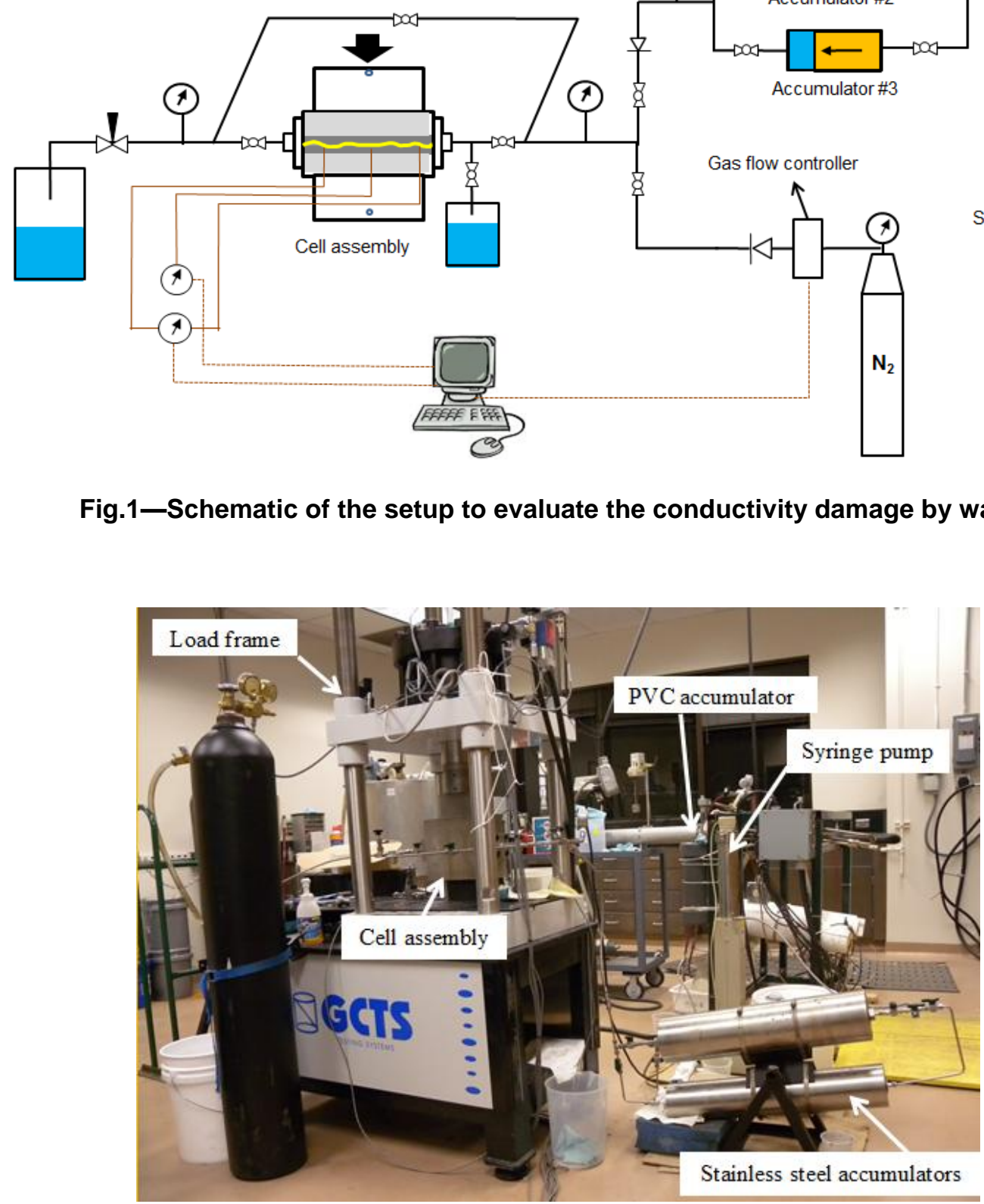

Fig.2-Photograph of the setup to evaluate the conductivity damage by water. 
Top and bottom

pistons

1

2

3

4

5

6

7

8

9

10

11

12

13

14

15

16

17

18

19

20

21

22

23

24

25

26

27

28

29

30

31

32

33

34

35

36

37

38

39

40

41

42

43

44

45

46

47

48

49

50

51

52

53

54

55

56

57

58

59

60

61

62

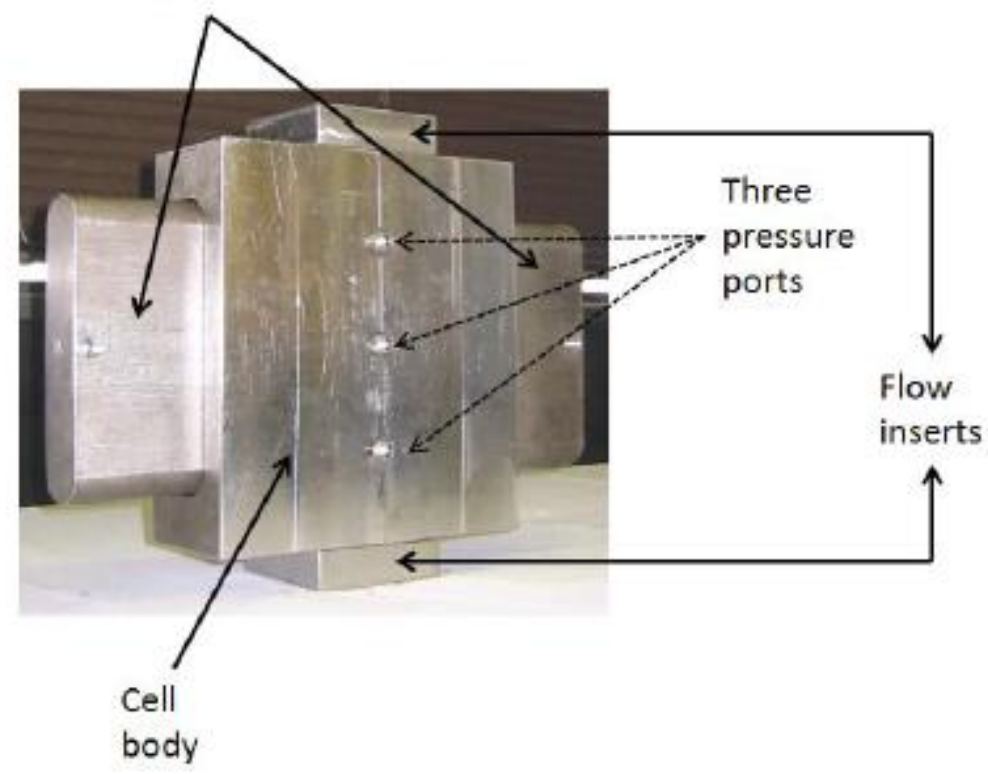

Fig.3-Modified API conductivity cell.

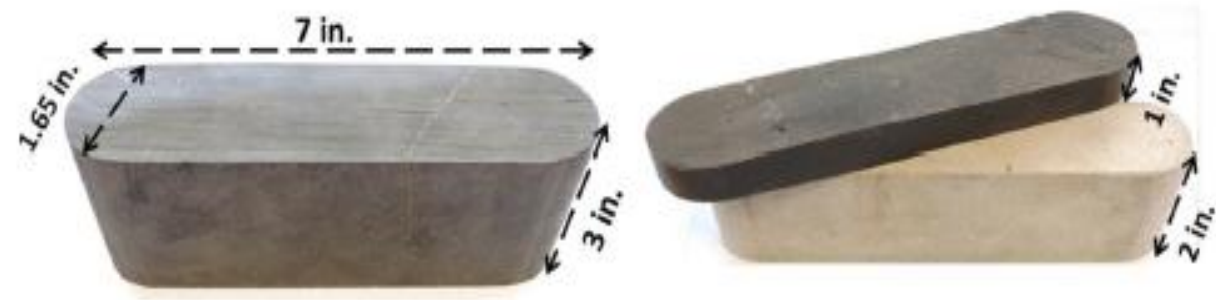

Fig.4-Shale samples and dimensions. 


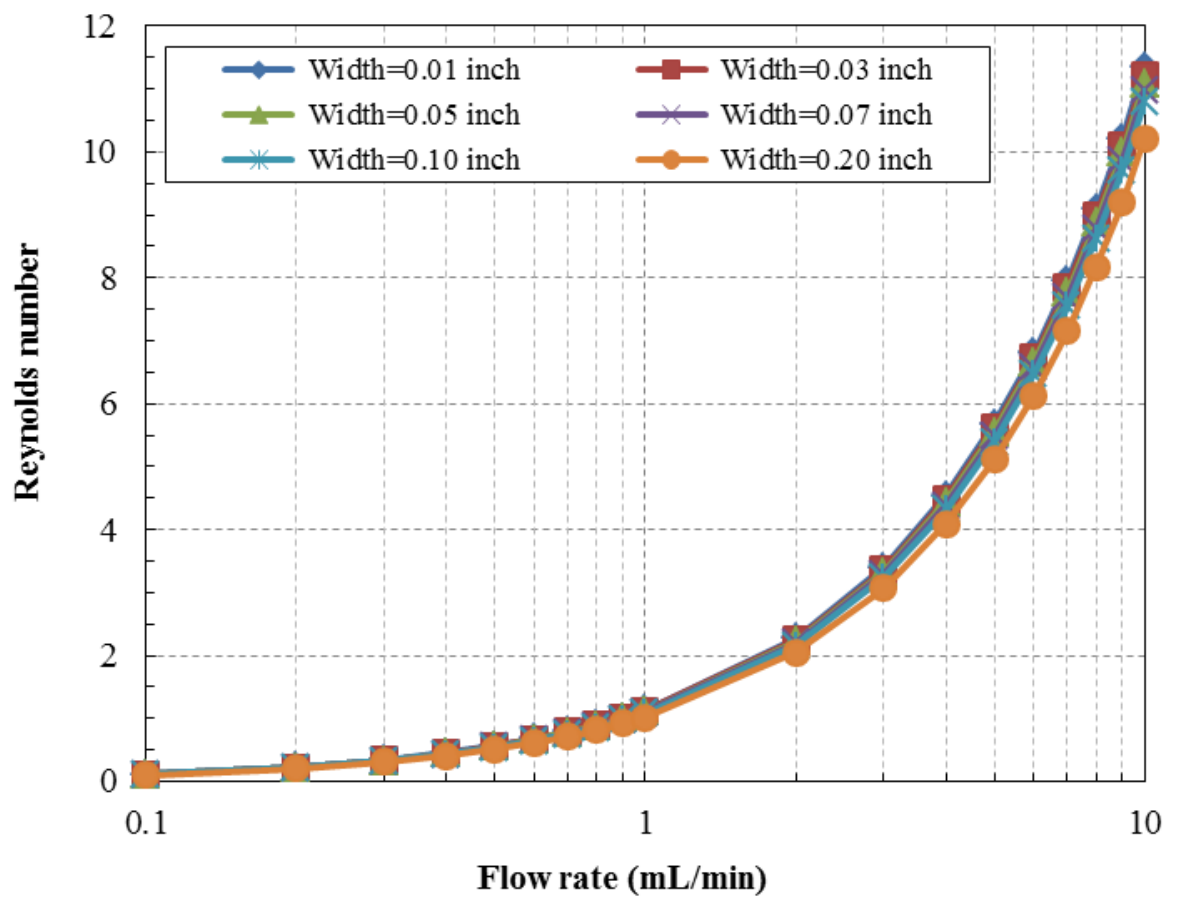

Fig.5-Reynolds number for the liquid flow at various fracture widths.

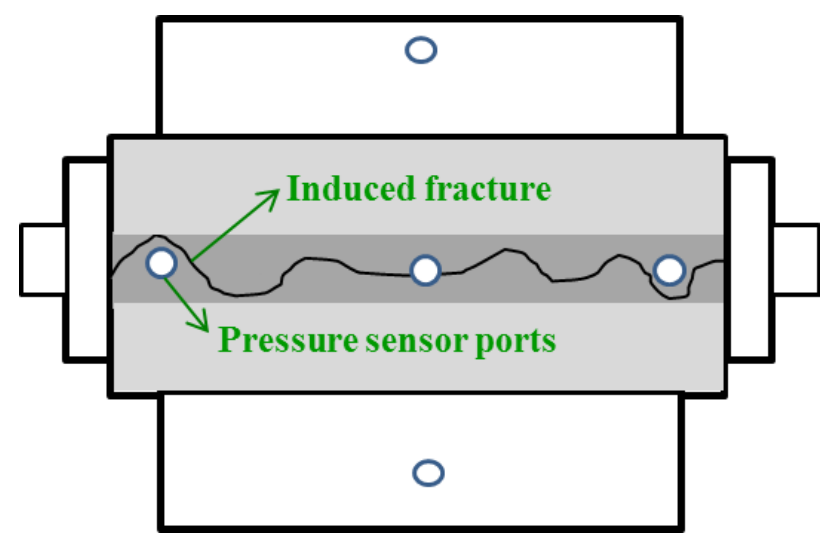

Fig.6-Induced fracture bypassing the pressure measurement ports.

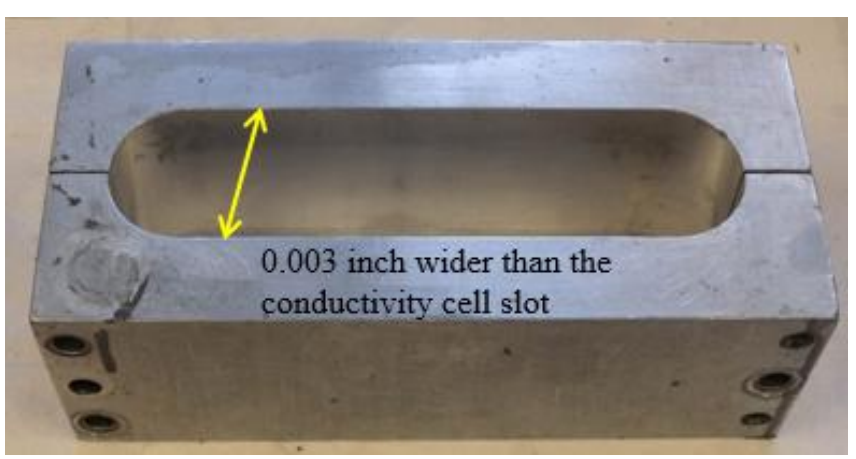

Fig.7-Silicone rubber compound coating mold. 

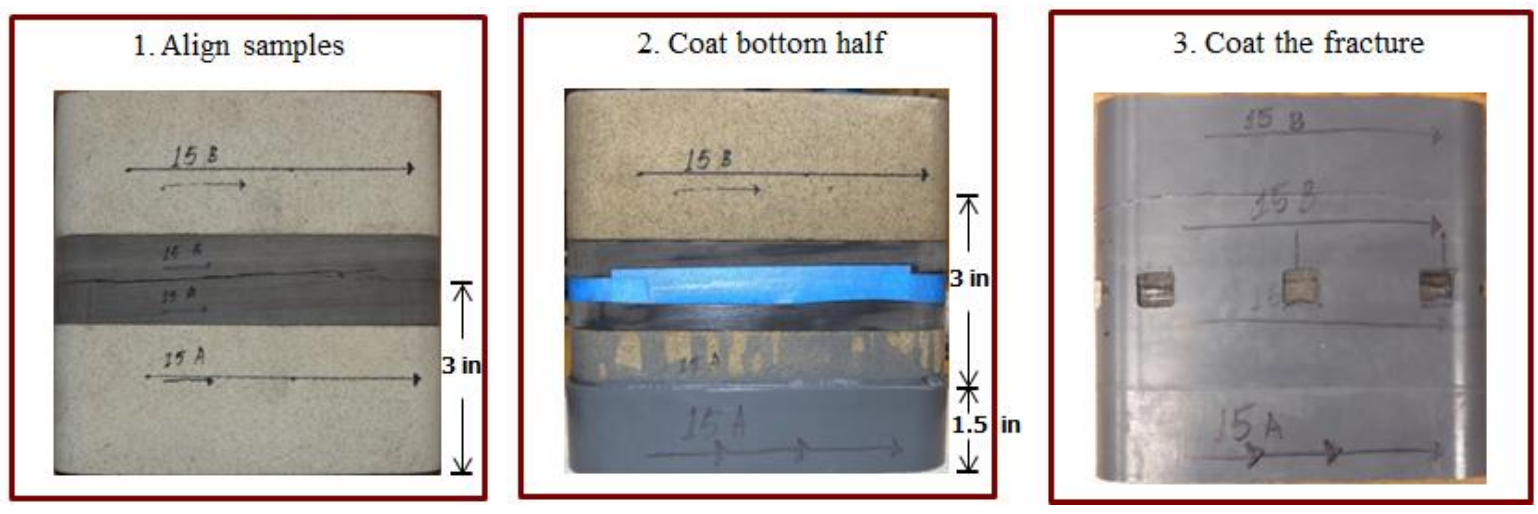

Fig.8-Procedures to coat the sample with silicone rubber.

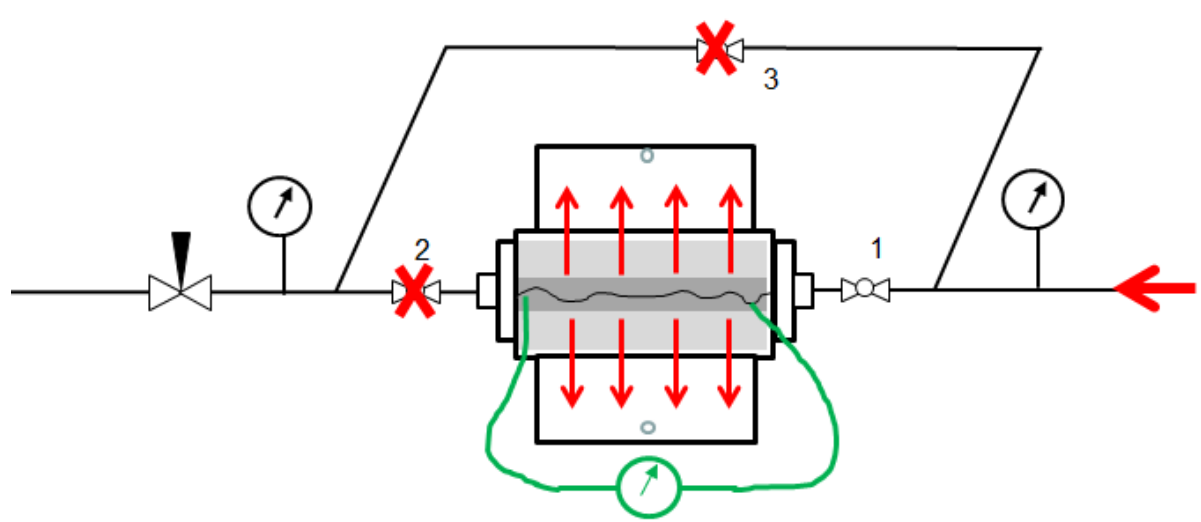

Fig.9-Pressure test the system to detect the vertical gas leakage.

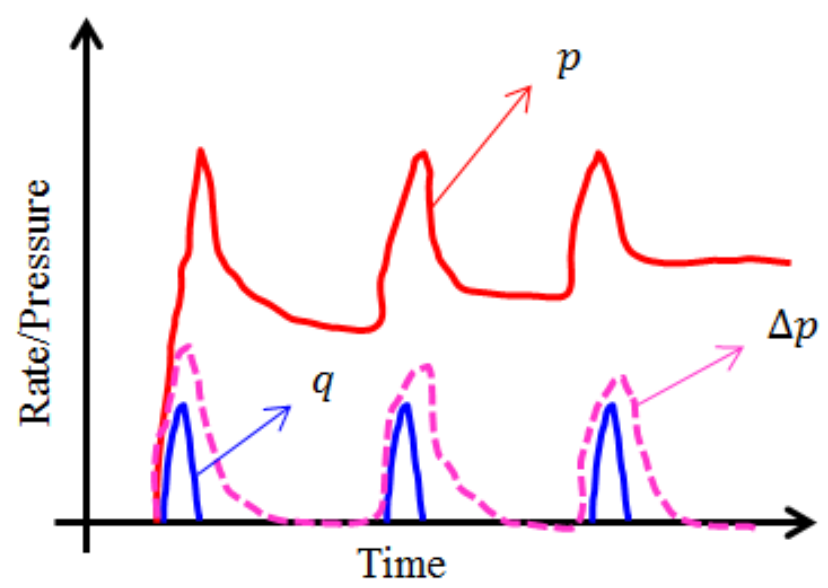

Fig.10-Pressure and rate response to flow impulse to detect the vertical leakage. 


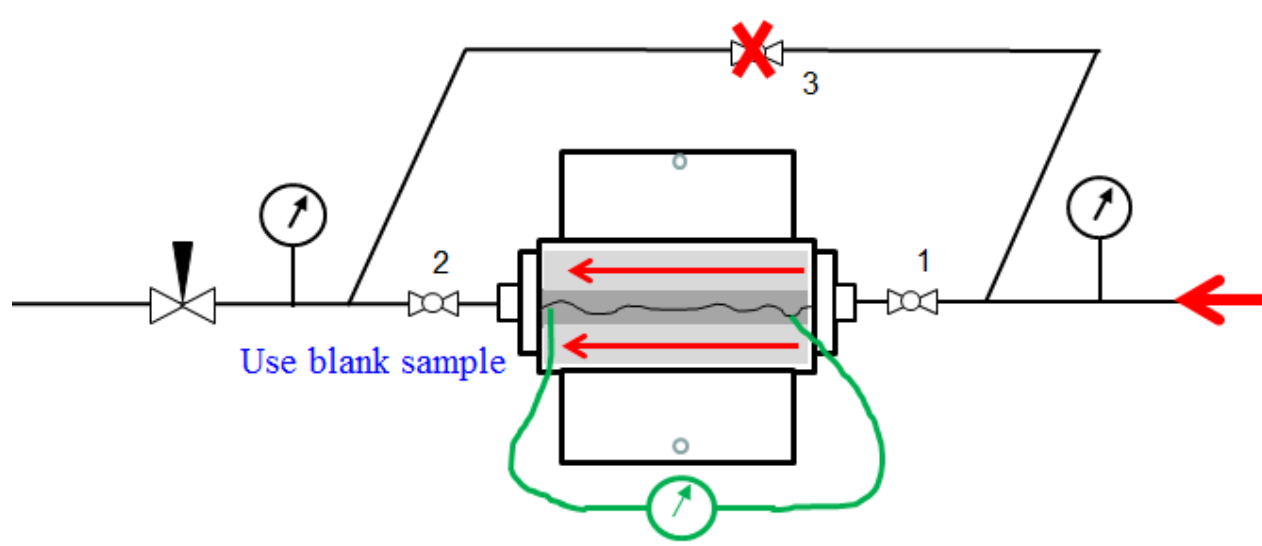

Fig.11-Pressure test the system to detect the horizontal gas leakage.

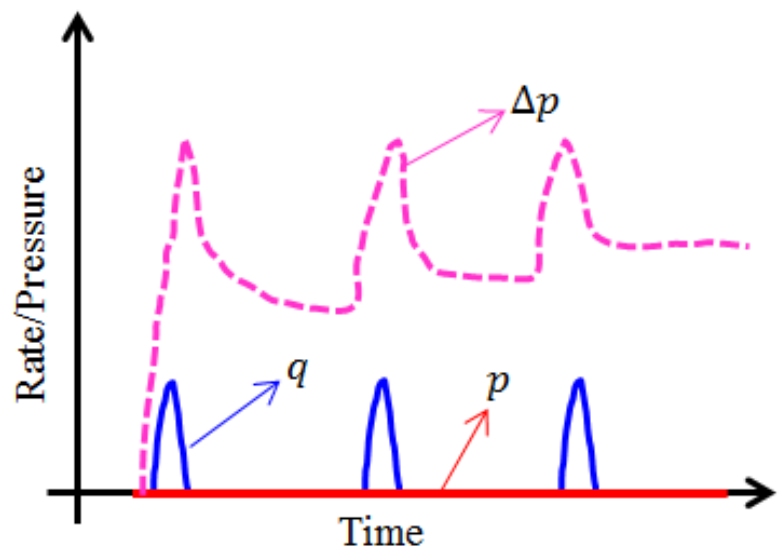

Fig.12-Pressure and rate response to flow impulse to detect the horizontal leakage. 


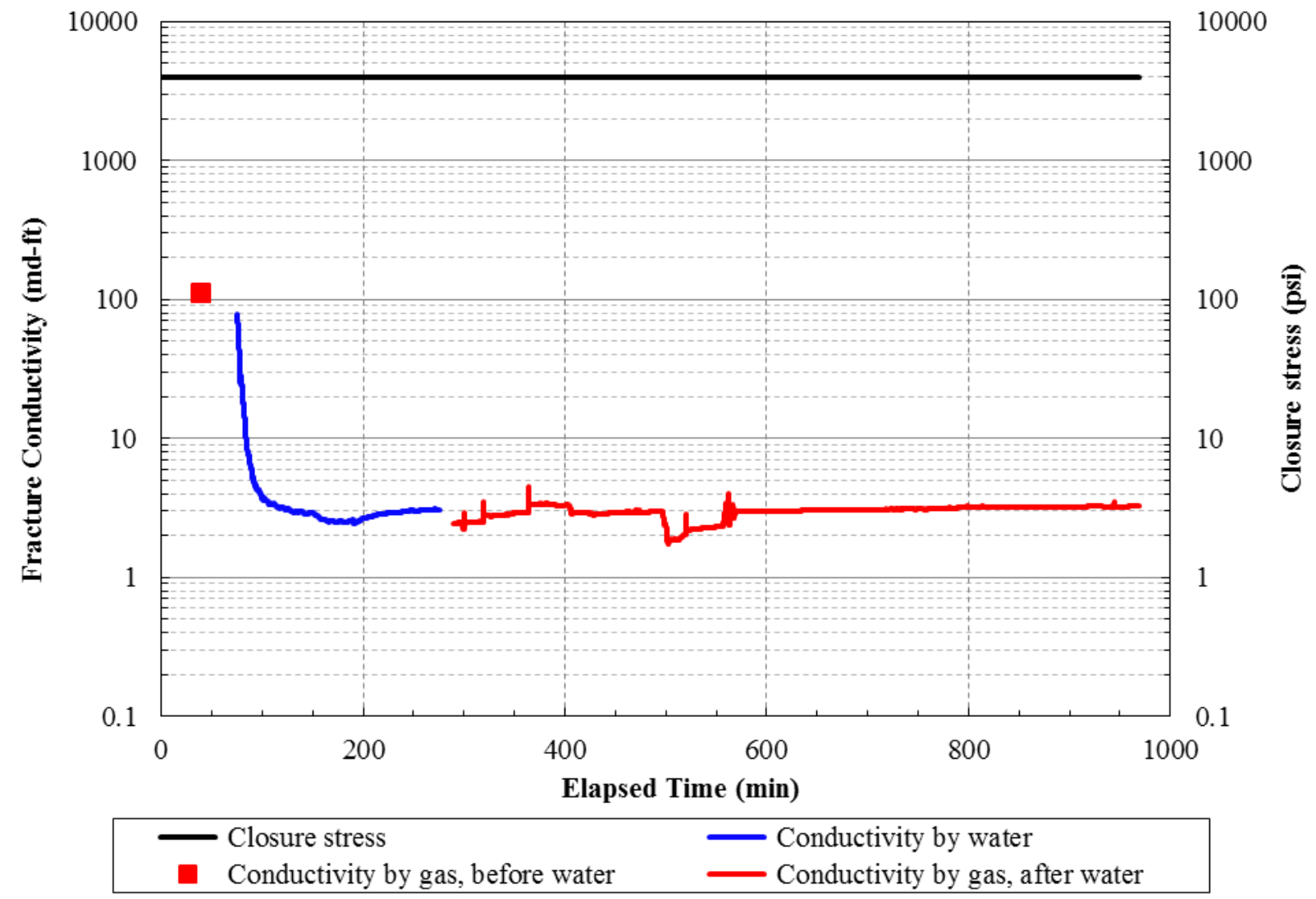

Fig.13-Fracture conductivities of the Barnett shale measured before and after water flow.

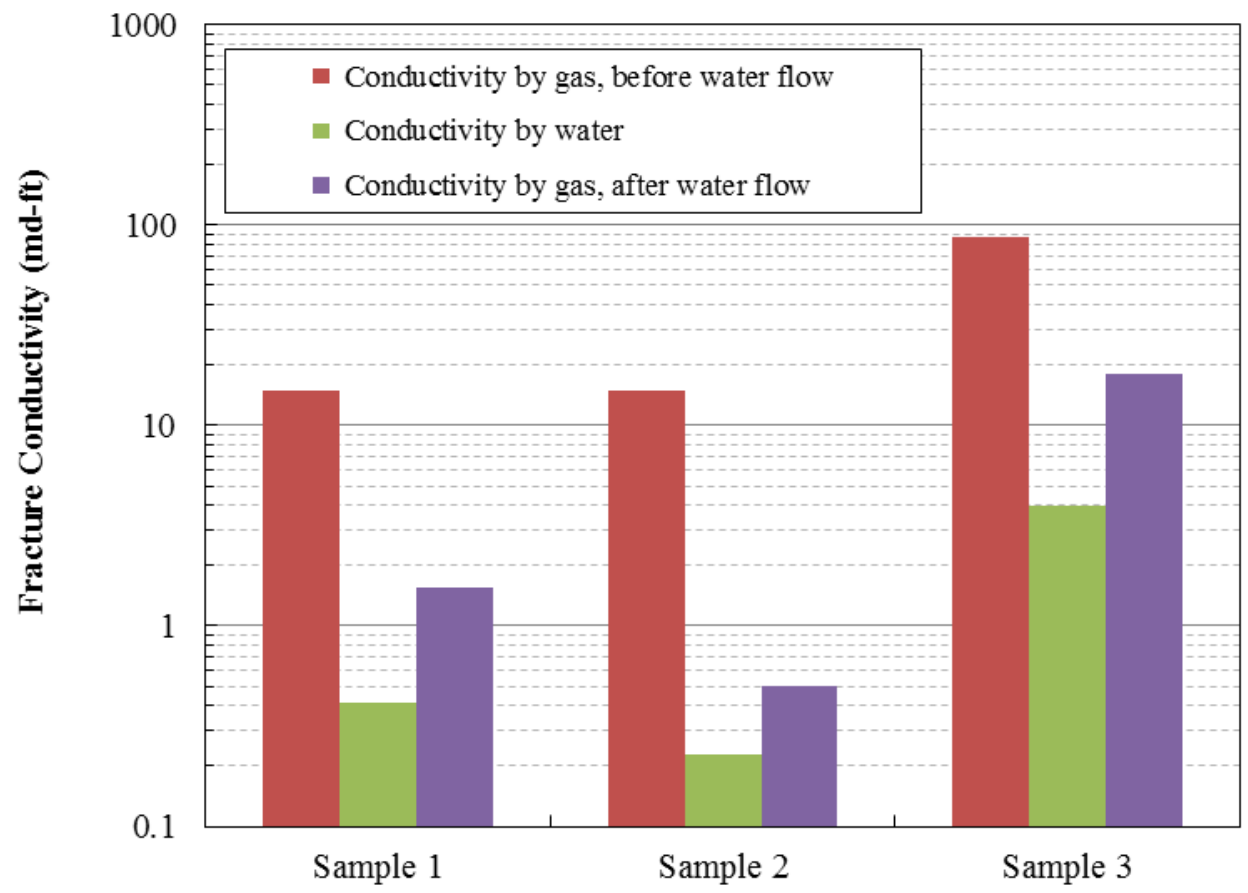

Fig. 14-Fracture conductivity measured by gas and water. All samples were measured at 4,000 psi closure stress. 


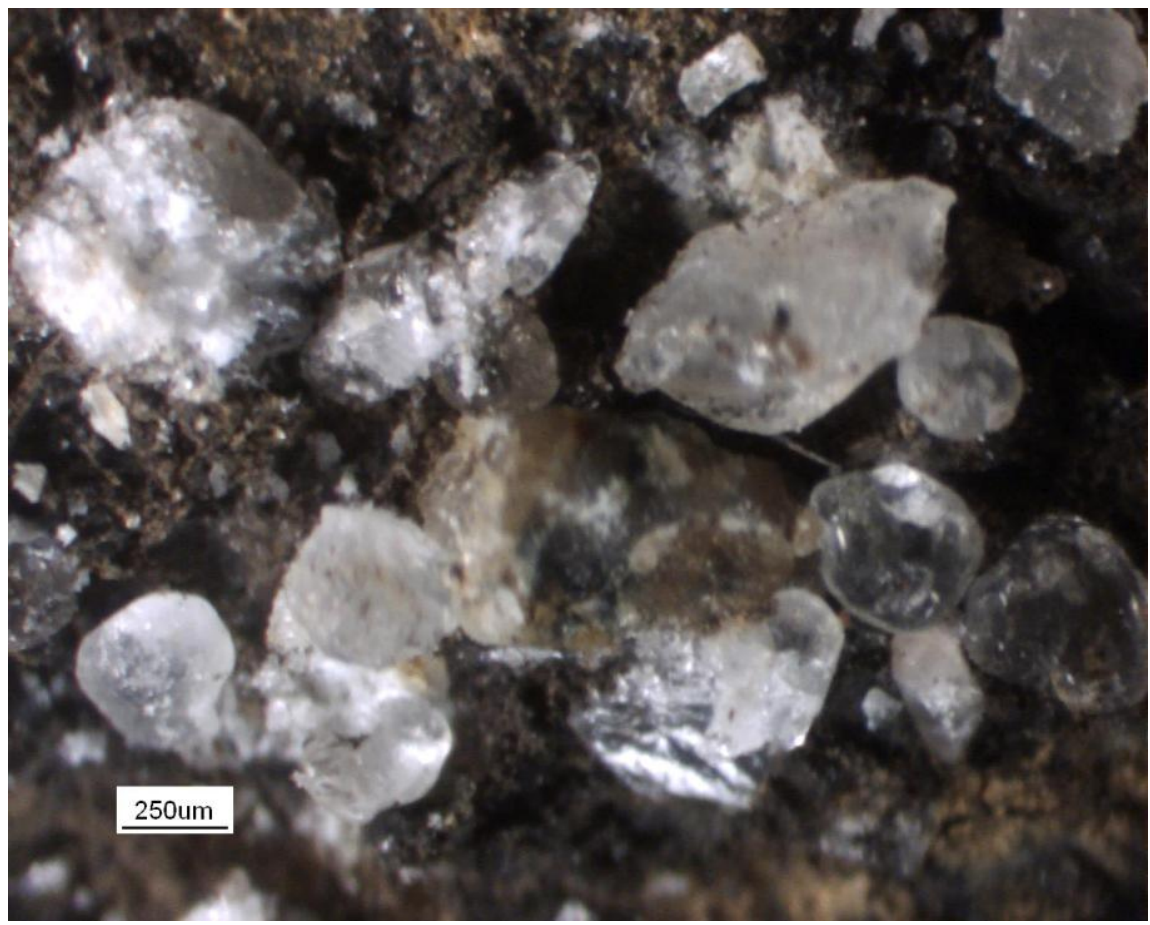

(a)

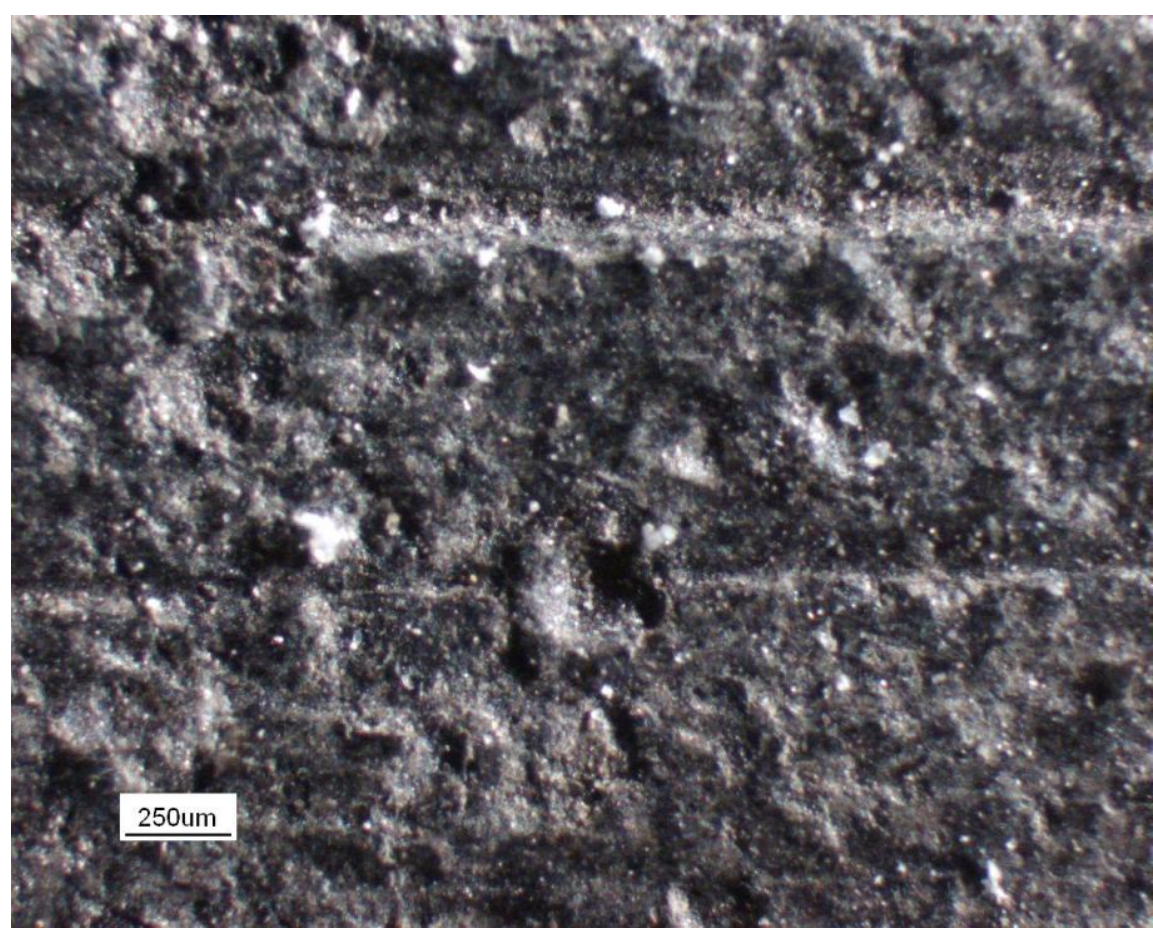

(b)

Fig. 15-Microscopic images of proppant embedment on the Barnett Shale fracture surface after conductivity measurement: (a) fracture exposed to water; (b) fracture exposed to gas only. 


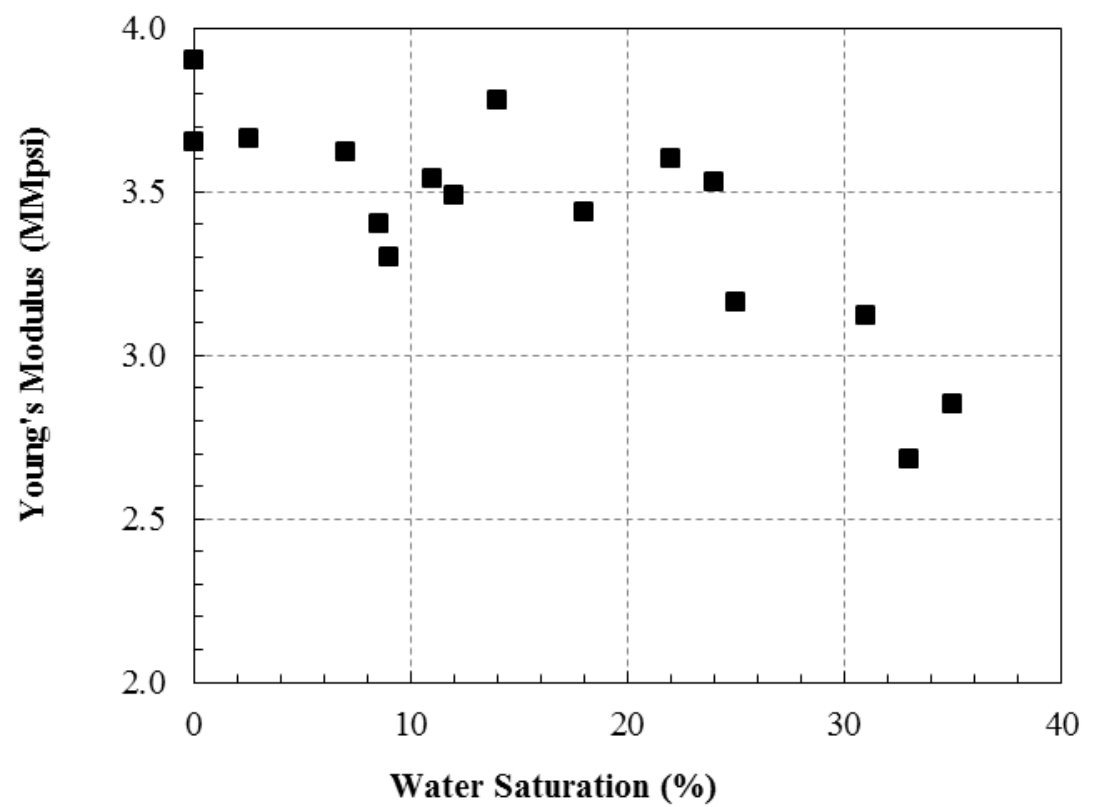

(a)

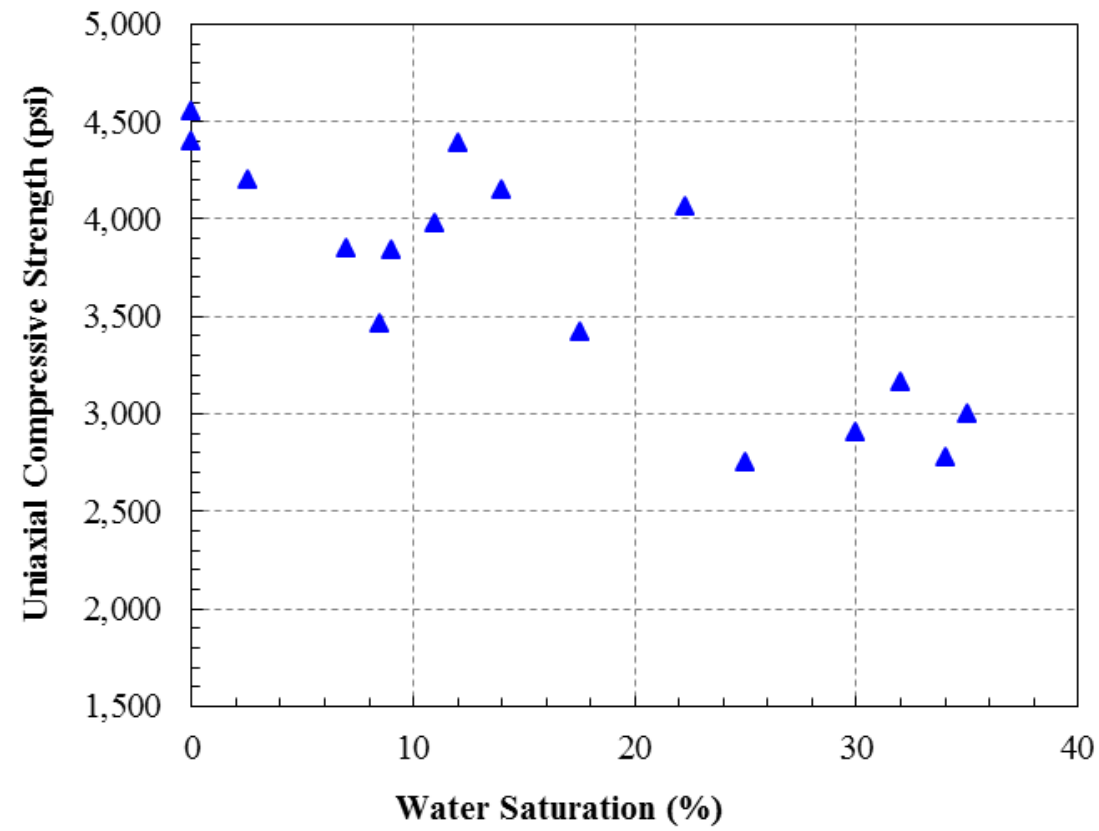

(b)

Fig. 16-Effect of water saturation on Barnett shale rock properties: (a) reduction of Young's Modulus; (b) reduction of uniaxial compressive strength (Lin and Lai 2013). 
Table 1-Chemical compositions of the reconstituted water sample in the Barnett shale (Horner 2011).

1

2

3

4

5

6

7

8

9

10

11

12

13

14

15

16

17

18

19

20

21

22

23

24

25

26

27

28

29

30

31

32

33

34

35

36

37

38

39

40

41

42

43

44

45

46

47

48

49

50

51

52

53

54

55

56

57

58

59

60

61

62

63

64

65

\begin{tabular}{ccc}
\hline Ions & Flowback water $(\mathrm{mg} / \mathrm{L})$ & $\mathrm{Lab}(\mathrm{mg} / \mathrm{L})$ \\
\hline $\mathrm{Na}^{+}$ & 12453 & 12646 \\
$\mathrm{Mg}^{2+}$ & 253 & \\
$\mathrm{Ca}^{2+}$ & 2242 & 2244 \\
$\mathrm{Sr}^{2+}$ & 357 & \\
$\mathrm{Ba}^{2+}$ & 42 & 0.0807 \\
$\mathrm{Mn}^{2+}$ & 44 & 0.0066 \\
$\mathrm{Fe}^{2+}$ & 33 & \\
$\mathrm{SO}_{4}^{2-}$ & 60 & \\
$\mathrm{HCO}_{3}^{-}$ & 289 & 9 \\
$\mathrm{Cl}^{-}$ & 23797.5 & 23170 \\
\hline $\mathrm{TDS}$ & 39,570 & 38,069 \\
\hline
\end{tabular}

